DePauw University

Scholarly and Creative Work from DePauw University

$10-5-2018$

\title{
Pedagogy of the 'not': Negation, Exodus, and Postdigital Temporal Regimes
}

Derek Ford

DePauw University, derekford@depauw.edu

Follow this and additional works at: https://scholarship.depauw.edu/educ_facpubs

Part of the Education Commons

\section{Recommended Citation}

Accepted manuscript of article originally published in: Ford, D.R. "Pedagogy of the 'not': Negation, Exodus, and Postdigital Temporal Regimes." Postdigit Sci Educ (2018). https://doi.org/10.1007/

s42438-018-0009-4 The final publication is available via Springer at: https://link.springer.com/article/ $10.1007 / \mathrm{s} 42438-018-0009-4$

This Article is brought to you for free and open access by the Education Studies at Scholarly and Creative Work from DePauw University. It has been accepted for inclusion in Education Studies Faculty publications by an authorized administrator of Scholarly and Creative Work from DePauw University. 
Pedagogy of the 'not': Negation, exodus, and postdigital temporal regimes

Abstract: Postdigital capitalist time is characterized by an incessant acceleration that homogenizes time and weds us to the present by making it so we have to constantly catch up and re/learn relearn the latest apps, social media configurations, operating systems, and so on. This reinforces imperialism, blocks resistance, and ensnares us in the present. To short-circuit this, I articulate an exo-exopedagogy to suspend postdigital time and free our subjectivity from its ensarement in the present. This provides an alternative educational mode of life to the lifelong learning apparatus that sustains postdigital capitalist time. Specifically, I turn to the "not," a fundamental and omnipresent word whose radical potential lies in its ability to clear out oppositions and open up a radical indeterminancy that is always untimely. Reading Paolo Virno's work on negation and exodus, I argue that negation entails an exodus from exopedagogy, one that alters the meaning and categories from which exopedagogy withdraws. As a concrete example of exo-exopedagogy, I offer a factional struggle inside the New York City Teachers Union. Before concluding, I spend some time with Sandy Grande's important critiques of Eurocentrism and progress in western critical education. I do this to demonstrate how a pedagogy of the not helps circumvent these past errors through its accommodation of — or, better, insistence on-variegated temporalities.

Keywords: exodus, time, sleep, suspension, negation, Paolo Virno

In the postdigital age, anything seems possible but everything seems impossible. On the one hand, any group can start a trending hashtag and radically intervene in and redirect a segment of popular discourse. Disparate groups of organizers and militants can connect, build, and coordinate actions and campaigns, linking different movements and spaces together into one (think Occupy). On the other hand, capital and state powers make their own interventions, blocking or demoting news sites critical of their power, or cutting off — or, in the case of Iran in 2009, not cutting off- - service. ${ }^{1}$ Even without considering the massive state and capital intervention in the digital age, we can still find the basis of this contradictory feeling of possibility and impossibility. The rapidity of the rise and fall of trending hashtags and their frequency of turnover makes the impact tenuous at best and doomed at worst. The intensity of the momentum of social movements or critiques is followed just as soon by naysays and movement critics.

The digitization of life began as a deeply contradictory process. The internet, which promised openness and equality only exacerbated economic and political inequality. As we use it to generate new connections, knowledges, and even political actions, our connections are expropriated by the corporations that own the digital platforms and other vital infrastructure (Dean, 2009). And while it was built by hackers and amateurs, it was a massive state and military operation (Jandrić \& Barbrook, 2017). I begin here by emphasizing these contradictions because, as Gregory Bourassa (2018) reminds us, the stories we tell about capitalism "register certain political sensibilities at a given moment" and "reveal hidden statements about social movements, anti-capitalist struggles, and the theoretical resources relied upon or developed in order to make sense of or discredit these movements and struggles" (pp. 1-2). Rather than the apocalypticism of capitalist realism that presents capitalism as an indomitable force, Bourassa begins his work with the ever-present fragility of neoliberal capitalism, a parasitic form of capital that relies not so much on exploitation but on appropriation. As such, Bourassa wants to produce forms of 
subjectivity autonomous from capital and its forms of life through postschool imaginaries. What I'm interested in, however, is how to nourish and enact a postdigital pedagogy in order to suspend postdigital capitalist time and free our subjectivity from its ensnarement in the present.

The paper begins with an examination of the role of time in ordering society, and the role of capitalist production in ordering time. I characterize postdigital time - a capitalist temporality - as an incessant acceleration that acts to homogenize time and wed us to the present by making it so we have to constantly catch up to the present. While the impulse of this is no doubt economic (the realization of value), it is crucially undergirded by a pedagogical logic wherein we have to perpetually learn and relearn the latest apps, social media configurations, operating systems, and so on. After giving a concrete example of how this temporal regime reinforces imperialism and blocks resistance, I bring in two strategies of refusal: sleep and idleness/solidarity. Both of these slow down time - for the simple reason that they take time - so we can detach from the present. What these political and economic strategies need, however, is another educational mode of life, without which they cannot overcome the pedagogical logic of postdigital time. To do this, I call on Paolo Virno's work on negation and articulate a pedagogy of suspension that initiates and sustains such a detachment, wresting us free from the neverending learning of the present. As an example of negation, the 'not' is a particularly powerful entry into suspension because of how fundamental it is to language and how omnipresent it is in practice. And yet the radical potential of this small word is constantly suppressed.

The 'not' clears out oppositions and thereby exposes us to a radical indeterminacy and potentiality that is always untimely. On first pass, this is the temporal axis of what Tyson Lewis (2012) calls exopedagogy, a kind of pedagogy immanent in social movements that moves past the public/private binary and toward the common. Yet Virno's writing on exodus draws out how his theory of negation augments exodus — and thereby exopedagogy — making it richer with even more alternatives and possibilities. To be specific, I argue that negation entails an exodus from exopedagogy, one that alters the meaning of the categories exopedagogy withdraws from (including the public and private). I present the factional struggle between the communists and professionalists inside the New York City Teachers Union to illustrate this exo-exopedagogy. Before concluding, I spend some time with Sandy Grande's important critiques of Eurocentrism and progress in western critical education. I do this to demonstrate how negation as suspension helps circumvent these past errors through its accommodation of — or, better, insistence onvariegated temporalities.

\section{Postdigital capitalist time}

Much more than an economic system, capitalism is a kind of temporal regime. Marx (1973) put it succinctly in his Grundrisse notebooks: "Economy of time, to this all economy ultimately reduces itself" (p. 173). Each society has to "order" time in at least one way, and in a society based on the maximization of profit, time is something - a commodity - with value insofar as it is that which allows for the production of surplus-value. The definition of capitalist value is, in fact, socially-necessary labor time, or the average duration of time it takes to produce a given commodity with the average skill, technology, and other conditions. Here, time is understood and experienced as chronological, wherein events unfold or develop in succession. A moment passes and another one arrives. That time is hegemonically configured as linear in education is confirmed by Anna Bennett and Penny Jane Burke (2017) in their study of time in higher education. They make a compelling argument that we need to reveal the taken for granted 
functioning of time as it is inscribed in the structures and relations of higher education by forefronting the historical and social construction of temporalities. They "highlight the importance of recognising that time does not exist apart from context and that it is not neutral; its constitutive parts are ontico-ontological" (p. 10). The plasticity of time is felt with the "speed up" of academia (Meyerhoff and Noterman, 2017).

The speed of capitalist temporality, in other words, is ever accelerating, which isn't a new phenomenon or something unique to the "neoliberal" era. As David Harvey (2010) reminds us, "we all too easily forget that the hour was largely an invention of the thirteenth century, that the minute and the second became common measures only as late as the seventeenth century and that it is only in recent times that terms like "nanoseconds' have been invented" (p. 147). Faster is always better. If time is fixed absolutely (whether that be measured by days or the life of the sun), then the tendency is to speed-up time relatively. The proliferation of digital networked technologies not only accelerates the time of production, but more importantly it extends the influence of capitalist temporality to all of life. Jonathan Crary (2013) characterizes contemporary capitalism as a system and an ideology of $24 / 7$, or "a generalized inscription of human life into duration without breaks, defined by a principle of continuous functioning. It is a time that no longer passes, beyond clock time" (p. 8). Defined by endless transitions and caught in a constant cycle of trying to catch up, the $24 / 7$ "intensified rhythm precludes the possibility of becoming familiar with any given arrangement" (p. 37). What Crary identifies is how the temporal regime of postdigital capitalism weds us to the present by positioning us as constantly behind, and so always having to catch up to, the present. Faced with a constant deluge of data and an endless chronology of catastrophes, confronted by the need to constantly learn (and relearn) our media platforms, we feel a contradictory mix of helplessness and urgency that keeps us looped into postdigital capitalism. That this temporality is postdigital means that the time of digital technology is no longer "separate, virtual, 'other' to a 'natural' human and social life" (Jandrić et. al., 2018, p. 893).

Maximilian Forte's (2012) study of the 2011 US and NATO-led imperialist war on Libya provides us with an instance of the real and devastating implications of this relationship between postdigital time and the contemporary capitalist regime, and how it blocks resistance and eliminates time for reflection, strategy, and solidarity. The 2011 war against Libya was justified by an invented humanitarian emergency in which there was no time to do anything but act. Those of us in the West were told by our governments that a popular uprising against a brutal dictator was not only being suppressed, but was facing immanent genocide. Politicians and media like CNN and al-Jazeera (owned by anti-Gaddafi royalty in Qatar) spread unfounded claims about "Gaddafi bombing his own people." There was no mention that both the US Secretary of Defense and a high-ranking admiral said there was "no confirmation of that" (p. 242). Forte's study not only shows that the conflict in Libya could at best be described as a civil war, and worse (but more accurately) as a rebellion of racist, Islamist, and pro-Western segments of society against a popular leader who came to power in an anticolonial struggle. ${ }^{2}$ It also-and more importantly for the purposes of this paper-shows how the temporality of the campaign against Libya prevented any dissent. Even so-called critical and anti-war activists and intellectuals like Noam Chomsky and Chris Hedges got on board to support the war effort. To be sure, time wasn't the only factor driving this constellation of forces, but it was an undergirding and enabling one.

Both Crary and Forte identify resistance as entailing restraint. Forte concludes his book with a plea. "The next time that empire comes calling in the name of human rights," he urges us, 
"please be found standing idly by" (p. 307). On the next morning we wake up to a new \#SaveXYZ hashtag in our timelines accompanied by news articles and politicians condemning and calling for immediate and swift action against a head of state, political party, or any individual or grouping, we should refuse the invitation to retweet our outrage. Solidarity isn't demanded immediately through blackmail ("you either support us or you support a baby-killing dictator!") but produced through "communication, exchange reciprocity, mutual knowledge, and trust" (p. 264). All of this, of course, takes time.

For Crary (2013), that which capitalism can never colonize or eliminate is sleep. Sure, capitalist can cut into our sleep, extend our working days through legal, illegal, and extralegal measures. It can degrade the quality and limit the quantity of our sleep, but it can never totally annihilate it. Sleep is also a necessarily a physical necessiaty and a social activity in which we are vulnerable to and dependent on others, and its common to us all. As the last barricade against 24/7 capitalism, sleep is a "radical interruption," and "a refusal of the unsparing weight of our global present where "the imaginings of a future without capitalism begin" (p. 128). Although Crary doesn't expand on this much, I imagine sleep as a barricade precisely because it is a blocked terrain from which one advances. The point is not just to sleep, but to advance from sleep to slow down more generally so we can be detached from the present. Yet in order to advance from sleep, we need to address the pedagogical logic of postdigital capitalist time: lifelong learning. More than that, we need to develop an alternative educational mode so that we don't merely sleep to wake back up to the same temporal regime. In what follows, I offer the suspension of negation as a pedagogical manner of initiating and sustaining such a detachment.

\section{Time as pedagogy}

There is a certain dominant temporality within educational institutions, settings, and relations in Western societies. Gert Biesta (2017) shows how the concepts of change, learning, development, schooling, the child, and progress are all fundamentally temporal in that they happen over time. Indeed, he notes that today time determines educational processes much more than any educational goals or content, as "the school day is over... when time is up, not when learning has finished" (p. 88). While Biesta homes in on time within the realm of education, there is a more generalized pedagogy of time, a phrasing I use to signal the educational force of time and how it disciplines us instead of the role of time in schooling and pedagogy. For example, under capitalism, time is commodified, endowed with an exchange value, something we can save, spend, waste, manage, give, and take. If we don't or can't discipline ourselves to time-ascommodity, if we don't or can't match the speed of our bodies and minds to the speed of capital, then we are discounted, disabled, even annihilated.

Recent literature in philosophy of education identifies the contemporary educational ordering of society as the learning society, which tightly binds us to the future (Ford, 2018a, 2018b; Lewis, 2017; Wozniak, 2016; 2017). As Tyson Lewis (2017) remarks, "The rhythm of learning is one that is always about the future, about guilt over the status of one's debt" (p. 26). The crushing weight of debt that we must repay structures so much of our lives and determines, if not the decisions we make, at least the coordinates within which we make such decisions ("I would declare this major but I don't think there will be employment opportunities," or "these are the majors I can declare because they have strong employment outcomes"). Jason Wozniak (2016) shows how, "credit is a time-disciplining technique. Those who lend money appropriate the time of those to whom they lend" (p. 75). If money is a representation and store of (socially- 
necessary) labor time, then credit is a claim on future labor-time. Our future obligations structure and delimit our present actions, instituting a rhythm of linear time as exchange value (Wozniak, 2017). The problem, in sum, is that we are so securely wedded to and entrenched in the present via the future that revolutionary breaks and upheavals are unthinkable, or thinkable only as impossible. One pervading manifestation of this is lifelong learning, wherein we must perpetually learn in order to update our skills, habits, qualifications, knowledges, and so on in order to remain competitive. With debt always over our heads, the demand to always learn exerts an almost unbearable force on our lives. In fact, we can even learn better sleep habits so that we can better maximize our productivity for capital! There are all sorts of improvement guides out there in magazines, on websites, and in books to help us re-learn how to sleep to more appropriately accommodate the dictates of the marketplace (e.g., Stanley 2018). ${ }^{3}$

A key task for those of us who want to create a post-capitalist world, then, concerns the theorization and enactment of alternative temporal pedagogies that function precisely to divorce us from the present. Negation is one such alternative, one that is particularly powerful because of how fundamentally it structures language and being. It's powerful, that is, because it is a ubiquitous yet untapped presence. Negation in the marxist tradition is often synonymous with, or closely related to, opposition. Thus, in a famous passage from the end of the first volume of Capital, Marx (1867/1967) shows how individual private property is negated into its opposite of capitalist private property, which in turn is negated into the opposite, "the possession in common of the land and of the means of production" (p. 715). Communism is, in other words, the negation of its opposite, capitalism, and through the negation of the negation capitalism becomes communism. This is a limited sense of negation - inherited from Hegel (or a particular reading of Hegel - that tethers it to a dialectical process that progresses through the unfolding of contradictions. To break through 24/7 capitalist time, we need a more radical sense of negation. While we could pursue negation in a number of places - from Theodor Adorno to José Esteban Muñoz-I want to turn to a recent book Paolo Virno to get to the politics, semiology, and the affect of the 'not.' This, in turn, helps me bridge the gap between time and politics via pedagogy.

As a fundamental linguistic particle, 'not' passes through our minds, out from our mouths, and on our screens often and without thought or even notice. As Virno (2018) argues, however, the 'not' is the universal equivalent of language and a powerful ontological and affective actor. As he proffers, the 'not' "participates in the description of the world and determines to a great extent the form assumed by the actions and passions of the human animal" (p. 53). Negation, I want to propose, can be developed as a pedagogical mode of encountering others, ourselves, and the world in a way that attunes us not to what is but to what could be through an emphasis on what is not, and which, in so doing, unfastens us from the present and suspends the tempo of 24/7. To articulate such a pedagogy, however, we have to move from the classroom to the structure of language, before moving back into the public sphere.

Negation on this reading doesn't signal what is opposite or contrary. To say that "I am not a good teacher" or "I do not like grading papers" does not mean that "I am a bad teacher" or "I hate grading papers." The "not' augments a predicate not by an antithesis but by "its opposition to all other signs, namely, by not being what they are" (p. 34). When I state, "I am not a good teacher," I mean that, as a teacher, I am anything other than good. Not only could I be an excellent or a terrible teacher, but I could also be a sick teacher, a problematic teacher, a stupid teacher, an unreliable teacher; literally any other kind of teacher. Negation implies difference without end: "I am not a good teacher" only means "I am different from a good teacher." There is no definition, only possibility and potentiality. And this is where the rich praxis of the not 
emerges: it opens up the subject and referent to an endless and infinite indeterminacy and potentiality. When it isn't followed quickly by a clarification ("I am not a good teacher, I am an $x$ teacher), when the negated semantic content is left hanging, so too are we. This is a minor pedagogical move. Its implications are not minor.

When negation isn't explicitly activated, it's still there as a condition of possibility of speaking and sense making. In this way, linguistic negation is thoroughly ontological, although it manifests as a present absence. In other words, it's only because we can say that something is not that we can say that something is. Negation thus keeps open the gap between the world and signification, between meaning and sense. Virno likens it to the Hebrew vowel aleph that serves as a backing for words but cannot itself be said (or heard). Negation is ontological because it installs a gap between the world and word, between sense and meaning. For example, we only know what it means when I remark, "that was a bold essay" because of the primary lingering 'not' before bold. This lingering 'not' stands in for the sum of the negative differences that constitute language. "Ontological negation," as Virno puts it, "institutes and preserves the neutrality of sense. By virtue of the gap that separates it from denotation and the illocutionary force (or, if you prefer, from the facts of the external world and psychic drives), the sense of a statement is always suspended between alternative developments, maintaining a perfect equidistance from them" (p. 81). Sense is separated from language and so concurrently positioned toward the 'not' and the content to which it is attached. This is not to say, of course, that all actions happen through language.

Suspension is the praxis of negation, which means that negation operates by keeping sense indeterminate to meaning and signification. Rather than suppressing, disavowing, or annihilating the stated content, negation retains even that which is negated. This is a rule of negation. Virno writes that when stating, "I do not mean to offend you," I am at the same time acknowledging my capacity to intentionally offend. "Rather than opposing and cancelling each other," Virno sums up, "this knowledge and this refusal are mutually sustaining: I know my intention to offend precisely because I refuse it; I refuse such an intention precisely because I know it. Both knowledge and non-acceptance realize themselves in the negative statement 'I have no intention to offend"" (p. 204). While the negation does not signal the contrary, it nonetheless sustains it. What is more, however, is that the operative negation also sustains all other potentialities. This is suspension in the fullest sense, without any exclusions whatsoever. The negation points to the stated content, the negated content, and everything else. In order to state "I am not studying" I must admit the act of "studying" into discourse and possibility even as I turn away from the act and toward everything besides studying. The most concise and indeterminate formulation here would be the double negative, "I am not not studying."

\section{Negation as the temporal axis of exo-exopedagogy}

The 'not' enacts the non-contemporaneity of sense and being with the present, an ontological attribute increasingly hidden or mitigated against in the postdigital era, in which everything is present all the time. Crary (2013) is right to claim that "our time is the calculated maintenance of an ongoing state of transition" (p. 37, emphasis added). Transition isn't new, of course, but historically between radical technological transitions there were periods of stability. While, say, the introduction of television inaugurated new kinds of social relations and perceptions, these were fixed for several decades. This is no longer the case in the postdigital age. Indeed, it's difficult now to call any technological development radical or revolutionary, because we know 
another one is just around the corner. And the promises of technological developments advancing justice or equality or any real common value are now in tatters.

In this configuration, negation offers us a constant suspension that can form a resistance, one that complements idleness and sleep by betraying the reality of postdigital capitalist temporality. ${ }^{4}$ If we really were bound to the present then negation would be impossible, for there would be no gap between meaning and sense:

The texture of any actuality, or presence, is assembled from environmental facts and emotional stimuli-from those facts and stimuli of which denotations and illocutionary forces are the doubles within statements. The autonomy of sense from denotation (i.e. from the fact) and from the illocutionary force (i.e. from the stimulus) thus implies its autonomy from all that we have good reason to consider as present. (Virno, 2018, p. 79)

Negation's praxis of suspension hinges on this non-contemporaneity and reveals and enacts the neutrality of sense. Negation allows for non-presence because it allows for that which is to be otherwise. If we could only ever affirm what is, then there would be no need for or possibility to be separated from the present. There would be no language, no difference, no possibility. The possible, as it turns out, always encompasses the its own negation: "When we say 'It is possible that you love me,' we also say at the same time 'It is possible that you do not love me"” (p. 99).

Through removing the subject from the present, the praxis of negation opens drives up to orientation and direction, potentially politicizing the drive and collectivizing the subject. In fact, negation conditions the intersection between epistemology and ontology, between word and action, the linguistic and non-linguistic. Negation is both "the logical tool that determines the discontinuity between linguistic praxis and drives" and "the key with which the former intervenes in the latter, altering their fate" (p. 180). There are two ways in which negation bridges drives and linguistic praxis. The first is as a threshold between the two, and the second is as an attachment that connects the two. In the first instance, the 'not' is located between the difference without positivity that makes language possible and the particular differences enunciated (between the being and the expression of language), while in the second instance it is located between what is done through language and what is done outside of language. These two are themselves linked: "negation enables the retroaction of statements on emotions and on instinctual behaviors only because it translates into a concrete discursive operation that detachment from the environment and that gap from the present that characterize language considered as a whole" (p. 185). Once subsumed under the praxis of negation, drives attain an independence and become susceptible to direction.

To make this less abstract, Virno gives the example of pain. The affirmation of pain ("I am in pain") is no more than a signal of a state, and so does not enable the independence or direction of the drive. The negation of pain ("I am not in pain") frees the drive by divorcing it from the feeling of pain. Limited to the affirmation of pain, the affect only exists when present, and its articulation is limited to the expression of the feeling. When negated, however, "pain does not disappear but, separating itself from the particular circumstances that have caused it, often gives rise to the feeling of our enduring, and hence irredeemable, vulnerability" (p. 194). The subject is thus removed from the present of pain as the painful affect is subjected to multifarious deployments. Negation, to put it differently, opens the drive up as it gives form to it. It also generalizes the subjects vulnerability to pain, for it bring to consciousness that one can not be in pain, establishing a different relation to pain, which is now free. Be that as it may, there is a 
distinct difference between this reality and our experiences, which leads Virno to declare that this difference or heterogeneity "acquires visibility and weight only when it asserts itself in praxis, transforming to a certain extent our vital conducts" (p. 206). There is the reality of negation, and the appearance of negation, and so the task is to show this struggle and to inhabit the gap in time opened up by the 'not.' This is one way in which to view the preparation for and inauguration of revolutionary events: the proclamation of the 'not.'

At first blush, the pedagogy of negation emerges as a form of exopedagogy, or education as exodus (Lewis, 2012). Opposed to oppositional logic, exodus entails, as Virno (2008) formulates it, "Neither A, nor not-A, neither resigned acquiescence nor struggle to seize power in a predetermined territory, but an eccentric B, achievable only as long as other premises are surreptitiously introduced into the given syllogism" (p. 148). Exodus refuses the available choices - the stated semantic content and its contrary - and finds recourse in the endless indeterminacy of negation. Without sublating the alternatives (A or not-A), exodus instead alters the cartography of struggle, taking advantage of alleyways and improvised passages, and inventing new cuts through the space of power. Let's take a strike as an example. During a strike, two sides (management and labor) struggle over wages, hours, and conditions. The options are to strike or fold, and the end-point for both sides is to reach a deal. An exodus from this situation wouldn't necessarily mean abandoning the strike or even bargaining but would explore other options and therefore shift the coordinates of the struggle. Let's say that during the strike the workers took over the factory and resumed production without the bosses. In this case, the framework for the struggle has shifted and yet the alterantives (strike or fold) are still in play. The position these alternatives play in the new terrain, however, are different than before, and the end-point of a successful agreement expressed through a new labor contract is no longer the only one available. The workers may decide to organize outside the union - through community organizations, religious groups, other unions, etc. - and expropriate the factory for good.

Virno (2004) also calls exodus a defection, an exit, which has the advantage of "unrestrained invention which alters the rules of the game and throws the adversary completely off balance" (p. 70). What's interesting in this formulation is that Virno acknowledges an adversary — or opponent — while opposing opposition. This could easily be read as a contradiction, and perhaps it is. In fact, given what Virno tells us about negation, calling exodus "neither A, nor not-A," makes exodus impossible, for there is nothing that is neither A nor not-A. A more generous reading, however, could see negation as enhancing and clarifying his earlier articulations of exodus. In modifying the terrain of conflict and antagonism, exodus actually alters both ends of A and the opposite of A. Stated otherwise, through moving within the suspension of the opposing alternatives, exodus redefines those very alternatives. What we have here is a thoroughly dynamic and relational conception of political struggle in which everything is on the table, even what appears to be off the table.

Lewis (2012) defines exopedagogy as "a pedagogy that is immanent to social movements that are global in nature and breaks significantly with the dialectic of the public versus the private" (p. 845). Both the private and the public expropriate and limit the common, the former for private property (capital) and the latter for public property (the state). Unlike the privatepublic dialectic, the common is a condition and end of production, in which what is produced returns to the common to enhance and extend it, in an intensifying spiral. ${ }^{5}$ Both capital and the state tame the surplus, and so block the productive capacities of the multitude as they deprive the multitude of its products. He identifies three moves that follow from this: politically (from citizen to pirate); metaphysically (from universal to the common, from particular to singular); 
and educationally (from judgment to decision) (p. 856). The educational philosophy that comes closest to the common is the deschooling of Ivan Illich. Illich removes education from the school in the same way that the common removes production from the public and the private. Lewis sees deschooling as "a piratical act that de-appropriates education as part of the commonwealth against the sanctity of public schooling and private interests" (p. 857).

Negation adds a temporal dimension to the political, metaphysical, and educational components of exopedagogy at the same time as it opens exopedagogy into new (old) possibilities. Pedagogy thus requires a move from the present to the non-present. More than another dimension, however, negation is a praxis that in turn enables the other moves for which Lewis calls. In other words, it is only once we are divorced from the present that we can defect from capital and the state. Nonetheless, it also requires an exodus from exopedagogy - and thus an exo-exopedagogy - in that it alters the alternatives or dialectical oppositions of the framework itself. It does so by opening up what the private and the public, the pirate and the citizen, might mean once suspension wrests them free from the current landscape. It does so by attuning us to all the possibilities beyond deschooling when one says "schooling is not education" or "schooling is not liberating." Thus, to wrest ourselves free from lifelong learning we may not abandon lifelong learning but rather negate it, keeping it in play but now susceptible to infinite alterations; exploring the infinite potentiality of lifelong learning.

This is one way to read the factional struggle between the communists and professionalists inside the New York City Teachers Union (TU). Founded in 1916, the TU became a formidable articulation of broader social struggles beginning in the 1930s. The victory of the communist faction in the union was a key part of the strength of the union. The union administration was always progressive, but when the communists began to organize within the union, they pushed the union further to the left precisely by opening up what a teacher was. The administration "emphasized professionalism, collaboration with management, and legislation as ways of improving the working conditions for teachers," while the communists "did not view teachers as professionals but as members of the industrial working class whose major objective was to take part in the struggle against capital" (Taylor, 2011, p. 16). The administration wanted to maintain the identity of the teacher, which entailed not only a collaborationist orientation toward the Board of Education, but more fundamentally limiting membership to full-time licensed teachers. The communists wanted to open membership up and to organize substitute, part time, and other non-licensed teachers. This followed the third party and then popular front lines of the Communist International, which called on communists to prioritize building mass movements. The communists won the internal struggle and membership surged. They did not abandon their identity as teachers, but opened the identity up in the hopes of radically reformatting the very coordinates that determined what a teacher was and could be. In other words, the communist teachers were not teachers.

\section{Past times}

Against the constant speeding-up of postdigital capitalist time, the suspension of negation interrupts the onslaught of transition and the constant catching up (and re-learning) we have to do. Yet what is particularly useful about Virno's work on negation is that it isn't a call for opposition or overturning, nor is it an uncritical celebration of the new or the different. It firmly breaks with a narrative of progress that structures so many variants of critical education. 
Negation, after all, is precisely not the inversion of the present for a new future; it's a heterogeneous operation that preserves, suspends, and innovates. The final move I want to make in this paper is to draw out how the temporal pedagogy of negation guards against Eurocentric and colonial narratives of progress and teleology through its release of heterogeneous temporalities and potentialities. ${ }^{6}$

Sandy Grande (2004) most forcefully highlights the danger of these narratives in education, including its various critical components. Her work is particularly important - and yet seldom considered - in educational philosophy, because it emphasizes how the most well-known philosopher of education, John Dewey's educational philosophy "presumed the colonization of indigenous peoples" in that his conceptions of democracy and nation-around which his educational philosophy flowed-were "built upon the notion of ever-expanding possibility" (p. 33) - the frontier. ${ }^{7}$ Further, for those of us on the Left, Grande both provides critiques of marxist and socialist politics while at the same time holding open the possibility that educational practices in this tradition can "inform indigenous struggles for self-determination" (p. 33). She is specifically interested in the project of revolutionary critical pedagogy, which she partly defends against what she says are unfounded critiques by Samuel Bowers. ${ }^{8}$

Grande finds many of Bowers' critiques against critical pedagogy to be justified, as "critical pedagogy is born of a Western tradition that has many components in conflict with indigenous cosmology and epistemology, including a view of time and progress that is linear and an anthropocentrism that puts humans at the center of the universe" (p. 88). She is more sympathetic to revolutionary critical pedagogy, which turns away from the Frankfurt School and back to Marx. Thus, revolutionary critical pedagogy doesn't valorize change in general (not all change is desirable). Yet she still cautions that this pedagogy "is prone to promulgating its own oppressive grand narratives by dismissing indigenous cultures as 'primitive' or precapitalist entities" (p. 88). In addition, the project "is conceived of inherently as a rights-based as opposed to a land-based project" (p. 116). And it seems, when many Leftists do turn to land they do so in a colonial way. This is Glen Coulthard's critique of the project of commoning in colonial settlerstates, as "the so-called commons are actually occupied lands that the First Nations have been struggling to recover for centuries" (Malott, 2016, p. 16).

What is considered "marxism" in academia, however, is a very limited and narrow field that is absolutely dominated by white men, particularly from Western Europe, such as the Frankfurt School theorists. But as Asad Haider reminds us in his book, Mistaken Identity, "the insights of this brilliant thinker, Karl Marx, did not belong to Europe... They had been refined and developed in Asia, Africa, and Latin America. Even here in the belly of the beast... black Americans had shown that this legacy could not be geographically confined" (p. 3). In other words, Benjamin, Bloch, Adorno, Virno, Negri, or Hardt don't have a monopoly on marxism (isn't it curious that theorists who haven't participated in the revolutions they write about carry more authority in academia than the ones who have participated and even led those revolutions, many of whom are indigenous to their land?) Harry Harootunian (2015) locates the fundamental error of Western marxism with a "preoccupation with a matured capitalism," which "risked sacrificing historical capitalism, if not the historical itself, as a subject of inquiry" (p. 5). Harootunian presents a careful reading of Marx, Lenin, José Carlos Mariátegui, Wang Yanan, Moritarō Yamada, and others to demonstrate the rich, complex, and variegated historical account of marxism and the politics that follow.

A central problem with Western marxism is that it reads Marx's analysis of formal and real subsumption as a historical account rather than as an analytical model. Formal subsumption 
is when capitalism takes what comes before it and subjects it to its logics (and pursues absolute surplus value). Under real subsumption, capitalism now produces what came before it and the production process is totally subsumed under capitalism as the search for relative surplus value begins. Under real subsumption, that is, all of production totally determined by capital. This is, for example, what provides the basis of Negri's autonomism and his recent work with Michael Hardt, in which the social or biopolitical has been totally subsumed by capital, to which there is no more outside. ${ }^{9}$ Harootunian importantly maintains that real subsumption was merely a model for Marx so that he could imagine what a totalized capitalism would look like, which would then enable him to articulate the components of such a system. At worst, real subsumption was a projection into the future. Harootunian argues that Lukács and later the Frankfurt School saw the commodity-form in all of society (assuming real subsumption had been realized) so that the commodity's "role had been transformed into one of a central performer in structuring modern social life" and "it had become more complex, inasmuch as it now frequently was made to exceed the form of wage labor and the objectification of social relationships. It now involved culture in the broadest sense" (p. 37). ${ }^{10}$ It's not hard to see how this informs theories of mass consumption, one-dimensional beings, and so on.

In reality, however, Marx saw capitalism as "housing" "a vast, heterogeneous inventory and 'conjuncture' of temporalities no longer stigmatized for having been cast out of time but rather as expressions of contretemps, simultaneous nonsimultaneities... contemporaneous noncontemporaneities or uneven times, and zeitwidrig, time's turmoil, times out of joint" (p. 23). Nothing perhaps reveals Marx's temporal openness as his suggestion that surviving communes in $19^{\text {th }}$ century Russia as progressive relative to capitalism. Particularly in his Grundrisse notebooks of the late 1950s, Marx "rejected any linear causality that envisaged a singularly progressive movement from one period or mode of production to the next... but rather saw the multilinear movements as taking place in different regions and among diverse peoples" (p. 48). It was these insights that thinkers in the Global South and elsewhere latched onto and developed. To give just one example, Mariátegui's historical account of Peru accounted for indigenous communities, forms of common ownership or cultivation, Spanish colonial feudalism, and a republican capitalism. This was made possible exactly "because Marxism was open to diverse regional historical experiences that historical materialism had to account for, instead of remaining narrowly constrained by a singular and singularizing dogmatic discourse applied to all situations" (p. 140).

The temporal goal of socialism is to abolish capitalism's abstraction of time, the way that it imposes a homogenous temporality on people through force. By expropriating land and labor, capital today disciplines us into a 24/7 temporal regime. But discipline is never total, and resistance always persists. The non-presence of negation is a pedagogical manner of combatting 24/7 capitalist time in order to disrupt it not for the sake of disruption, but to allow for other temporalities, possibilities, and forms of life to emerge. For this reason, negation is a marxist practice in that it calls for, invites, and enacts nonlinear and disparate times. What's important to note here is that these alternatives are not only new or unforeseen alternatives. To be sure, suspension is definitely not any kind of march forward to overcome the past, and it doesn't operate according to the logic or dictate of the one. As an exodus from exopedagogy, the suspension of negation redefines the "citizen" from which Lewis urges educational philosophy to move to forms of belonging and forms of sovereignty that are totally separate from and precede the capitalist state. Exopedagogy as exodus thus does not ignore or preclude, but precisely makes space for non-Western forms of citizenship and publicness in a non-deterministic way. As such, 
the pedagogy of the 'not' is a bountiful and much needed praxis for coalitions and united fronts in political and social struggles against postdigital capitalism today, and a pedagogy of the not can counter the lifelong learning dictates that prop up the postditigal capitalist temporal regime.

This is not the end.

References

Bennett, A., \& Burke, P.J. (2017). Re/conceptualising time and temporality: an exploration of time in higher education, Discourse: Studies in the Cultural Politics of Education, DOI: 10.1080/01596306.2017.1312285.

Biesta, G.J.J. (2017). The rediscovery of teaching. New York: Routledge.

Bourassa, G.N. (in press). Postschool imaginaries: Educational life after neoliberalism. Policy Futures in Education, online first, 1-21.

Crary, J. (2013). 24/7: Late capitalism and the ends of sleep. New York: Verso.

De Lissovoy, N. (2011). Pedagogy in common: Democratic education in the global era. Educational Philosophy and Theory, 43(10), 1119-1134.

Dean, J. (2009). Democracy and other neoliberal fantasies: Communicative capitalism and left politics. Durham: Duke University Press.

Ford, D.R. (2015). From standardized testing to the war on Libya: The privatization of U.S. education in international context. In B. Porfilio and M. Abendroth (Eds.), Understanding neoliberal rule in K-12 schools: Educational fronts for local and global justice (95-109). Charlotte: Information Age Publishing.

Ford, D.R. (2015). The pneumatic common: Learning in, with and from the air. Educational Philosophy and Theory, 47(13-14), 1405-1418.

Ford, D.R. (2018a). Politics and pedagogy in the "post-truth" era: Insurgent philosophy and praxis. New York: Bloomsbury.

Ford, D.R. (2018b). Queer communist study: The sinthomostudier against the capital-learningdebt regime. Journal of Curriculum and Pedagogy, 15(1), 8-23.

Forte, M. (2012). Slouching towards Sirte: NATO's war on Libya and Africa. Montreal: Baraka Books.

Gautreaux, M. (2017). Revitalizing the common(s) in New Mexico: A pedagogical consideration of socially engaged art. In A.J. Means, D.R. Ford, and G.B. Slater (Eds), Educational commons in theory and practice: Global pedagogy and politics, pp. 249-269 (New York: Palgrave Macmillon).

Grande, S. (2004). Red pedagogy: Native American social and political thought. Lanham: Rowman \& Littlefield.

Haider, A. (2018). Mistaken identity: Race and class in the age of Trump. New York: Verso.

Hardt, M., \& Negri, A. (2000). Empire. Cambridge: Harvard University Press.

Harootunian, H. (2015). Marx after Marx: History and time in the expansion of capitalism. New York: Columbia University Press.

Harvey, D. (2010). A Companion to Marx's Capital. New York: Verso.

Horne, J. (2011). The end of sleep: "Sleep debt' versus biological adaptation of human sleep to waking needs. Biological Psychology, 87, 1-14. 
Jandrić, P., \& Barbrook, R. (2017). How to be modern: A situationist social democrat's adventures in radio, gaming and the internet, in P. Jandrić, Learning in the age of digital reason (pp. 75-104). Rotterdam: Sense.

Jandrić, P., Knox, J., Besley, T., Ryberg, T., Suoranta, J., \& Hayes, S. (2018). Postdigital science and education. Educational Philosophy and Theory, 50(10), 893-899.

Lewis, T.E. (2012). Exopedagogy: On pirates, shorelines, and the educational commonwealth. Educational Philosphy and Theory, 44(8), 845-861.

Lewis, T.E. (2017). Inoperative learning: A radical rewriting of educational potentialities. New York: Routledge.

Malott, C.S. (2016). History and education: Engaging the global class war. New York: Peter Lang.

Marx, K. (1867/1967). Capital: A critique of political economy (vol. 1), trans. S. Moore \& E. Aveling. New York: International Publishers.

Marx, K. (1973). Grundrisse: Foundations of the critique of political economy (rough draft), trans. M. Nicolaus. New York: Penguin Books.

Noroozi, N. (2016). Pedagogy of time and a decolonial "present." In N. Levinson (ed.), Philosophy of Education Society Yearbook 2016 (420-430). Illinois: University of Urbana-Champaign.

Meyerhoff, E., \& Noterman, E. (2017). Revolutionary scholarship by any speed necessary: Slow or fast but for the end of this world. ACME: An International Journal for Critical Geographies.

Richardson, T.A. (2007). Vine Deloria Jr. as a philosopher of education: An essay of rememberance. Anthropology and Education Quarterly, 38(3), 221-230.

Richardson, T.A. (2012). Disrupting the coloniality of being: Toward de-colonial ontologies in philosophy of education. Studies in Philosophy and Education, 31(6), 539-551.

Slater, G.B. (2015). Constituting common subjects: Toward an education against enclosure. Educational Studies, 50(6), 537-553.

Stanley, N. (2018). How to sleep well: The science of sleeping smarter, living better and being productive. Cornwall, UK: Wiley.

Taylor, C. (2011). Reds at the blackboard: Communism, civil rights, and the New York City Teachers Union. New York: Columbia University Press.

Virno, P. (2004). A grammar of the multitude: For an analysis of contemporary forms of life, trans. I. Bertoletti, J. Cascaito, and A. Casson. Los Angeles: Semiotext(e).

Virno, P. (2008). Multitude: Between innovation and negation, trans. I. Bertoletti, J. Cascaito, and A. Casson. Los Angeles: Semiotext(e).

Virno, P. (2018). An essay on negation: Towards a linguistic anthropology, trans. L. Chiesa. York: Seagull Books.

Wozniak, J. (2017). Towards a rhythmanalysis of debt dressage: Education as rhythmic resistance in everyday indebted life. Policy Futures in Education, 15(4), 495-508.

\footnotetext{
${ }^{1}$ For the first example, think of Twitter's banning of promoted ads by Russia Today and Sputnik (two sources highly critical of the U.S. government), or Facebook's censoring of Safa, a Gaza-based news site. For the second example, think of when the Egyptian regime of Hosni Mubarak blocked social media. In the case of Iran in 2009, the U.S. intervened and got Twitter to delay scheduled maintenance so that the U.S.-friendly and backed Green Movement could continue coordinating protests and attacks. For more on this, see the introduction in Ford (2018a).
} 
${ }^{2}$ This isn't unique to Libya at all. The same thing happened (and is happening) with Syria, and it's only a matter of time until it happens (again) with Iran, the Bolivarian Republic of Venezuela, and the Democratic People's Republic of Korea (DPRK, or North Korea), and so on. For more on Libya, see Ford (2015).

${ }^{3}$ Some contest the claim that we sleep less today than previously (e.g., Horne 2011). This research identifies that our "sleep deficit" has less to do with a lack of sleep and more to do with the stress and pace of our live (Horne 2011, p. 3). Horne importantly critiques a romancization of past sleep times. In fact, when one reads testimony about working conditions in English factories in the $17^{\text {th }}$ and $18^{\text {th }}$ centuries, it's clear that sleep duration was far from ideal. What this research doesn't challenge is that there is an inherent antagonism between sleep and capital.

${ }^{4}$ I mean 'betray' in both senses of the word: both to break from and to reveal.

${ }^{5}$ For more on education and the common, see De Lissovoy (2011), Ford (2015), Gautreaux (2017), and Slater (2015).

${ }^{6}$ Curry Malott (2016) provides a careful consideration of Indigenous critiques of marxism in his book's first chapter.

${ }^{7}$ This is not to imply that settler-colonialism isn't considered in education. For examples of this, see the work of Troy Richardson (e.g., 2007; 2012) and the work of the Latin American Philosophy of Education Society. Noroozi (2016) uses Derrida to address the relationship between pedagogy, time, and the decolonial.

${ }^{8}$ See chapter 2 in Grande (2004), especially pages 80-88.

${ }^{9}$ See in particular chapter 2.6 of Empire (Hardt and Negri, 2000).

${ }^{10}$ It's important to note here that Harootunian acknowledges that Lukács' theories were more complex, and he deals with them elsewhere in his book. 